\title{
DEBATE
}

\section{small states in world markets: 1985-2010}

\section{christine ingebritsen}

Department of Scandinavian Studies, University of Washington, Box 353420, Seattle WA 98195, USA

doi: $10.1057 /$ eps.2010.22

\begin{abstract}
What is the institutional legacy of Katzenstein's 1985 work on international relations theorizing? This article places Small States in World Markets in the history of the study of power. Katzenstein's contribution endures by identifying the relationship between changes in the world economy and the capacity of states to adapt. His 1985 book opened up new paths of theorizing - from the role of norms to the ways in which smaller political economies in Europe can inform the large. Even though the issue-areas, actors, and measures of power and authority evolve, Katzenstein's analysis remains a critical benchmark for institutional/IR analysis.
\end{abstract}

Keywords power; democratic corporatism; neocorporatism; European integration; flexible adaptation; the greening of capitalism

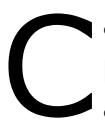
an a political economy analysis published in 1985 retain its academic relevance 25 years later? Does the work travel well to other small European states in light of recent developments in global markets, new security threats and the salience of environmental vulnerabilities? Are Katzenstein's institutional arrangements enduring, outdated, or does the framework itself 'flexibly adapt' to new global challenges?
These questions are the focus of three scholars, Herman Schwartz (University of Virginia), Baldur Thorhallsson (University of Iceland), and Christine Ingebritsen (University of Washington), who discuss the enduring footprint of the publication of Small States in World Markets, and who mentor, teach and conduct research in Europe and the United States in international relations and comparative political economy.

\section{About the Author}

Christine Ingebritsen is Professor of Scandinavian Studies at the University of Washington in Seattle, Washington. She received her Ph.D. in Government from Cornell University in 1993. Ingebritsen's research focuses on the five northern European states comprising the Nordic area. She has written two books, The Nordic States and European Unity; and Scandinavia in World Politics and co-edited Small States in International Relations; Globalization, Europeanization and The End of the Scandinavian Model; and Coming Out of the Cold War. Her current research focuses on Scandinavia's eco-entrepreneurship and the greening of capitalism. 